\title{
EFFECT OF DIFFERENT COAGULANTS AND VARIOUS CONCENTRATIONS ON QUALITY OF JACK BEAN TOFU
}

\author{
Rini Yanti*, Widiastuti Setyaningsih, Priyanto Triwitono, Richa Yuniansyah, \\ Ermi Saraswati Maha Admi
}

Department of Food and Agricultural Product Technology, Faculty of Agricultural Technology,

Gadjah Mada University, Yogyakarta, Indonesia

\author{
*Corresponding author \\ Email: riniyanti@ugm.ac.id
}

\begin{abstract}
Jack bean (Canavalia ensiformis), Indonesian local bean, has a high content of protein and great potential either for substituting or overcoming the shortage of imported soybean in tofu production. However, an appropriate coagulant in a proper amount is needed to make tofu with acceptable characteristics. This study set out to investigate the appropriate type and concentration of coagulant. The experiment was carried out by using GDL (glucono delta lactone) and nigari as coagulants with concentration levels of 0.25; 0.5; 0.75 and 1\%. Some quality parameters such as yield, color, texture (hardness, cohesiveness, chewiness, springiness), and microscopic structure of tofu were observed. Consumer preference tests on aroma, color, taste, texture, and overall acceptability were directed to determine tofu with the best characteristics. The result showed nigari at concentration level $0.75 \%$ delivered the most preferred tofu for consumers.
\end{abstract}

Keywords: glucono delta lactone, jack bean, nigari, tofu

\section{Introduction}

Tofu is a daily food that is very popular in Indonesia because it has a cheap price and high protein content. Tofu offers some important nutrients because of its comparatively huge number of vitamins, minerals, proteins, lipids, and isoflavones (Kim et al., 2020; Wang et al., 2019; Zheng et al., 2020). According to protein consumption data from Indonesian Central Statistical Agency (BPS, 2020), tofu is the highest type of protein source consumption in Indonesia (0.2021 $\mathrm{kg} /$ capita/week). However, the low soybean production in Indonesia compared to its consumption makes Indonesia have to import 1.24 million soybean tons per year (Riniarsi, 2016). To overcome the lack of soybean, it is necessary to use local beans as raw materials for producing tofu.

Jack bean (Canavalia ensiformis) is a local bean that has not been widely used in Indonesia. This bean contains high protein between 22.8-35.3\% db (Sridhar \& Seena, 2006). Solomon (2018) described that protein content of jack bean is $25.3 \%$ while soybean is $43.80 \%$. Although the content of jack bean protein is lower than soybeans, however, the amino acids composition are very similar to soybean. This fact is expected to give the possibility to produce a good quality tofu

Tofu preparation procedures comprise soaking, grinding beans in water, filtering, boiling, coagulation, and pressing. The yield and quality of tofu have been described to be affected by coagulants such as the type or concentration of coagulants (Jayasena et al., 2014; Oboh, 2007). The quantity of coagulant added in making tofu is one of the important things because it regulates 
the texture, aroma, and yield of the product (Li et al., 2013) There are 4 types of coagulant, such as salt (calcium chloride, calcium sulfate, magnesium chloride), acid (glucono delta lactone/GDL), enzymatic coagulants (microbial transglutaminase), and others (chitosan, guar gum). Every type of coagulant have different possible mechanism in tofu production (Zhang et al., 2018)

Therefore, this research was carried out to study the impact of different coagulants and various concentrations on quality of jack bean tofu.

\section{Methods}

\subsection{Materials}

Jack beans from Faculty of Agricultural, Sarjanawiyata Tamansiswa University, Yogyakarta. The coagulants used were Magnesium chloride Nigari (Sari Bahari) from Tasudo Shop Malang and GDL (Glucono Delta Lactone) from Subur Kimia Jaya Jakarta.

\subsection{Proximate Analysis of Raw Jackbean}

Moisture (method 925.10), ash (942.05), protein (method 10 950.36), and fat (method 963.15) contents of the jack bean samples were analyzed by AOAC (2000) method, while carbohydrate content of the jack bean was determined by difference.

\subsection{Preparation of tofu}

Jack beans (Canavalia ensiformis) were washed and soaked in water for 48 hours at $26-28{ }^{0} \mathrm{C}$. Water was added to hydrate the bean in a 3:1 ratio, were ground using blender using a blender (Philip). The slurry was filtered through cheesecloth and squeezed by hand pressure to obtain the extract called "milk".

Jack bean milk $(600 \mathrm{ml})$ was heated, then the coagulant is added manually at $63^{\circ} \mathrm{C}$ while stirred manually by a paddle. The stirring is continued until 60 times/30 seconds (30 rpm). The coagulant solution/suspension made by dissolving/mixing $(0.25,0.5,0.75$ and $1 \% \mathrm{w} / \mathrm{v}$ of the milk) Glucono Delta Lactone (GDL) and Nigari (sea salt). After adding the coagulant, the temperature was left until reached $96{ }^{\circ} \mathrm{C}$ and boiled for 1 minute. The coagulated curd was left until 15minutes and then moved to a mold $(8 \mathrm{~cm} \times 8 \mathrm{~cm} \mathrm{x} 4 \mathrm{~cm})$, the whey fraction was drained off gravimetrically, and pressed for 20 minutes using a weight of $5 \mathrm{~kg}$. The jack bean tofu was removed from the cheesecloth and weighed. The yield of tofu was calculated based on the weight of tofu compared to dried jack bean $(107 \mathrm{~g})$.

\subsection{Determination of Textural Properties}

The tofu texture profile was determined using TPA Nexygen (Texture Profile Analysis). An object was obtained from the central portion of raw tofu and it cut into cubes $(4 \mathrm{~cm} \mathrm{x} 2 \mathrm{~cm} \times 2 \mathrm{~cm})$. The treatments were carried out by 3 replications. A cylindrical probe was used for the examination with a speed of $0.5 \mathrm{~mm} / \mathrm{s}$ and a $15 \mathrm{~mm}$ diameter. The TPA settings used were: Test speed: 0.5 
$\mathrm{mm} / \mathrm{s}$, Distance: $30 \%$, Time between bite: $0.5 \mathrm{~s}$.

\subsection{Determination of Color Properties}

Tofu color was analyzed using Chromameter (CR-400) Minolta Reflectance and expressed as $L^{*}$ (lightness), $a^{*}\left(+a^{*}=\right.$ redness, $-a^{*}=$ greenness $)$ and $b^{*}\left(+b^{*}=15\right.$ yellowness, $-b^{*}=$ blueness $)$ color coordinates according to the methods specified by the equipment manual.

\subsection{Determination of Microstructure of Jack Bean Tofu}

Tofu was cut to $5 \times 5 \times 5 \mathrm{~mm}$ cubes and dehydrated in freeze drier. Dried samples were placed on aluminum stub and the microstructure of jack bean tofu were detected by scanning electron microscope (SEM) (JEOL-JSM-6510, USA)

\subsection{Sensory Analysis}

A total of 45 semi-trained panelists from the Gadjah Mada University students participated in the sensory evaluation. Eight jack bean tofu samples were used for sensory evaluation. Samples were cut into rectangular pieces $(2 \mathrm{~cm} \times 2 \mathrm{~cm} \times 2 \mathrm{~cm})$ and deep-fried for 10-12 minutes in commercially palm oil (Sovia from Mirota Kampus). Tofu samples were placed in paper cups which were labeled with 3 digits random numbers. Panelists were also served with crackers and water for the purpose to cleanse the palate between evaluations. The sensory attributes evaluated were color and overall acceptance. The seven-point Hedonic scale $(1=$ dislike very much, $2=$ dislike moderately, $3=$ dislike slightly, $4=$ neither, 5= like slightly, $6=$ like moderately, $7=$ like very much) was used.

\section{Results and Discussion}

\subsection{Proximate Analysis of Raw Jackbean}

The proximate analysis of raw jack bean showed that the moisture (12.65\%), crude protein $(23.97 \% \mathrm{db})$, fat $(5.25 \% \mathrm{db})$, and ash $(3.88 \% \mathrm{db})$ contents of jack bean samples were in the range from previous studies (Sridhar \& Seena, 2006). The content of jack bean protein $(23.97 \% \mathrm{db})$ was lower than the soy protein content $(37.69-43.80 \% \mathrm{db})$ (Solomon et al., 2018). According to (Maneepun, 2003) protein content in most legumes are ranged from $22.3 \%$ to $39.2 \%$, except soybeans. While carbohydrate content (by difference) of jack bean was $70.15 \%$. The nutrient content in plants depends on environmental factors, the strain, and processing methods, thus the results obtained from this experiment were slightly different from the reference.

\subsection{Yield}

The different coagulants (GDL and Nigari) showed significant differences in the yield of tofu $(\mathrm{p} \leq 0.05)$ (Figure 1). Nigari coagulants have higher yield than GDL. Coagulation using nigari occurs slowly. The slower the coagulating action of the coagulant, the better yield of tofu obtained than rapid-acting ones (Obatolu, 2008) The use of too much nigari gives tofu which has a low bulk 
yield (the curds will be very small and hard), is quite firm and has a slightly bitter flavor and uneven splotchy texture (Shurtleff \& Aoyagi, 2000). GDL is acid type of coagulant that would decrease the $\mathrm{pH}$. The fact of decreasing the $\mathrm{pH}$ affects the speeds up the coagulation reaction speed but decreases soymilk and tofu yields (Shurtleff \& Aoyagi, 2000).

Table 1. Yield (\%) of tofu made from different coagulants and various concentration

\begin{tabular}{cccccc}
\hline & \multicolumn{5}{c}{ Concentration (\%) } \\
Coagulants & 0.25 & 0.5 & 0.75 & 1 & Average \\
\hline GDL & $133.55 \pm 13.22$ & $117.56 \pm 8.49$ & $114.26 \pm 3.57$ & $105.68 \pm 5.90$ & $117.76 \pm 12.83^{\mathbf{x}}$ \\
Nigari & $147.36 \pm 6.78$ & $140.00 \pm 5.28$ & $128.01 \pm 5.77$ & $124.90 \pm 3.95$ & $135.07 \pm 10.58^{\mathbf{y}}$ \\
\hline Average & $140.45 \pm 12.06^{\mathbf{p}}$ & $128.78 \pm 13.83^{\mathbf{q}}$ & $121.14 \pm 8.67^{\mathbf{q r}}$ & $115.29 \pm 11.45^{\mathbf{r}}$ & \\
\hline
\end{tabular}

Note: Different Superscript indicated significant difference of result $(p<0,05)$ on Two Way Anova Test and Duncan Multiple Range Test

\subsection{Texture}

Textural properties including hardness, cohesiveness, chewiness, springiness of jack bean tofu was summarized in Table 2, 3, 4, and 5 respectively.

Table 2. Effect of different coagulants and concentration on hardness characteristics of jack bean tofu

\begin{tabular}{cccccc}
\hline & \multicolumn{5}{c}{ Concentration $(\%)$} \\
Coagulants & 0.25 & 0.5 & 0.75 & 1 & \multirow{2}{*}{ Average } \\
\hline GDL & $4.23 \pm 0.12$ & $5.10 \pm 0.51$ & $6.13 \pm 0.55$ & $6.65 \pm 1.15$ & $5.53 \pm 1.14^{\mathbf{x}}$ \\
Nigari & $3.02 \pm 0.13$ & $3.42 \pm 0.32$ & $4.28 \pm 0.46$ & $4.93 \pm 0.71$ & $3.91 \pm 0.87^{\mathbf{y}}$ \\
\hline Average & $3.62 \pm 0.67^{\mathbf{p}}$ & $4.26 \pm 13.00^{\mathbf{p}}$ & $5.20 \pm 1.117^{\mathbf{q}}$ & $5.79 \pm 1.27^{\mathbf{q}}$ & \\
\hline
\end{tabular}

Note: Different Superscript indicated significant difference of result $(p<0,05)$ on Two Way Anova Test and Duncan Multiple Range Test

Table 3. Effect of different coagulants and concentration on cohesiveness characteristics of jack bean tofu

\begin{tabular}{cccccc}
\hline & \multicolumn{5}{c}{ Concentration (\%) } \\
Coagulants & 0.25 & 0.5 & 0.75 & 1 & \multirow{2}{*}{ Average } \\
\hline GDL & $0.42 \pm 0.03$ & $0.45 \pm 0.04$ & $0.48 \pm 0.02$ & $0.50 \pm 0.04$ & $0.46 \pm 0.04^{\mathbf{x}}$ \\
Nigari & $0.32 \pm 0.03$ & $0.34 \pm 0.03$ & $0.42 \pm 0.01$ & $0.44 \pm 0.01$ & $0.38 \pm 0.06^{\mathbf{y}}$ \\
\hline Average & $0.37 \pm 0.06^{\mathbf{p}}$ & $0.40 \pm 0.07^{\mathbf{p}}$ & $0.45 \pm 0.03^{\mathbf{q}}$ & $0.47 \pm 0.04^{\mathbf{q}}$ & \\
\hline
\end{tabular}

Note: Different Superscript indicated significant difference of result $(p<0,05)$ on Two Way Anova Test and Duncan Multiple Range Test

Table 4. Effect of different coagulants and concentration on chewiness characteristics of jack bean tofu

\begin{tabular}{cccccc}
\hline & \multicolumn{5}{c}{ Concentration (\%) } \\
Coagulants & 0.25 & 0.5 & 0.75 & 1 & \multirow{2}{*}{ Average } \\
\hline GDL & $1.61 \pm 0.15$ & $2.14 \pm 0.95$ & $2.81 \pm 0.30$ & $3.06 \pm 0.73$ & $2.40 \pm 0.80^{\mathbf{x}}$ \\
Nigari & $0.88 \pm 0.16$ & $1.26 \pm 0.33$ & $1.45 \pm 0.12$ & $1.59 \pm 0.18$ & $1.30 \pm 0.33^{\mathbf{y}}$ \\
\hline Average & $1.24 \pm 0.42^{\mathbf{p}}$ & $1.70 \pm 0.79^{\mathbf{p q}}$ & $2.13 \pm 0.77^{\mathbf{q r}}$ & $2.33 \pm 0.94^{\mathbf{r}}$ & \\
\hline
\end{tabular}

Note: Different Superscript indicated significant difference of result $(p<0,05)$ on Two Way Anova Test and Duncan Multiple Range Test 
The results in Table 2, 3, 4, 5 showed that different coagulants contributed a significant difference $(\mathrm{p} \leq 0.05)$ on all texture characteristics such as hardness, cohesiveness, chewiness, and springiness value. While different concentrations affected hardness, cohesiveness and chewiness, however, it did not have significant difference for springiness. In addition, interaction between treatments had no significant difference $(\mathrm{p} \leq 0.05)$.

Table 5. Effect of different coagulants and concentration on springiness characteristics of jack bean tofu

\begin{tabular}{cccccc}
\hline & \multicolumn{5}{c}{ Concentration (\%) } \\
Coagulants & 0.25 & 0.5 & 0.75 & 1 & \multirow{2}{*}{ Average } \\
\hline GDL & $0.86 \pm 0.02$ & $0.86 \pm 0.01$ & $0.86 \pm 0.03$ & $0,86 \pm 0.01$ & $0.86 \pm 0.02^{\mathbf{x}}$ \\
Nigari & $0.82 \pm 0.01$ & $0.84 \pm 0.02$ & $0,84 \pm 0.02$ & $0.85 \pm 0.01$ & $0.84 \pm 0.02^{\mathbf{y}}$ \\
\hline Average & $0.84 \pm 0.02$ & $0.85 \pm 0.02$ & $0.85 \pm 0.03$ & $0.85 \pm 0.01$ & \\
\hline
\end{tabular}

Note: Different Superscript indicated significant difference of result $(p<0,05)$ on Two Way Anova Test and Duncan Multiple Range Test

\section{Hardness}

Tofu produced from GDL had higher hardness value than nigari. Nigari can be used to make firm and silken tofu, depend on press weight and time. GDL jack bean tofu has higher hardness value. GDL is commonly used to make regular or firm tofu. The hardness value is influenced by the water content trapped in the tofu matrix, the more water held in the matrix, the smaller the hardness value given (Shurtleff \& Aoyogi, 2000). Silken tofu has a brittle matrix so more water can be trapped in higher volume. On the other hand, hard tofu has a denser curd matrix which reduces its ability to retain water. In addition, pressing during the producing process induces the water in the curd matrix to come out, therefore make it harder

\section{Cohesiveness}

GDL provides greater cohesiveness when compared to nigari. The difference in texture characteristics due to different types of coagulant used can be attributed to higher water content and the possibility of incomplete precipitation of proteins, resulting in loose tissue that includes a lot of air in a compact protein network (Shen et al., 1991)

\section{Chewiness}

Chewiness is described as the energy required to grind a solid food to a state of willingness for ingesting and is instrumentally quantified as a product of hardness $\mathrm{X}$ cohesiveness $\mathrm{X}$ springiness (Rekha \& Vijayalakshmi, 2013). Consequently, Tofu with greater chewiness is stiffer and harder to eat. In this study, jack bean tofu was coagulated by GDL revealed a higher chewiness value than nigari, so that potential to be harder to eat.

\section{Springiness}

Springiness which is a measure of the recovery in height after the compression during the time that lapses between the end of the first bite and the start of the second bite (Chavan et al., 
2017), was highest for the tofu which coagulates with GDL, while there was no significant difference in springiness among a different concentration of coagulant

\subsection{Microstructure of Jack Bean Tofu}

SEM images of the tofu prepared using the different coagulants and different concentrations are available in Figure 1.

SEM micrographs of tofu coagulated with different coagulants show different fine structures, while the microstructure of tofu prepared with different coagulant concentrations was showed a slightly similar pore pattern. The microstructure of GDL tofu gel was compact while nigari tofu indicated large-small pore. This micrograph is in line with the result of texture analysis which GDL indicated higher hardness that nigari. According to (Shi et al., 2020) the different measures of microstructure indicated the different capability of holding protein and other soluble substances leading to different texture characters. Figure 1a and 1b, jack bean tofu prepared with GDL, showed a very compact surface and bumpy pores thus making it hard to trap water and other soluble matters into the gel and feasibly explaining the inferior texture and low yield of the tofu (Guo et al., 2018). This fact was correlated to the yield of jack bean tofu data in Table 1.

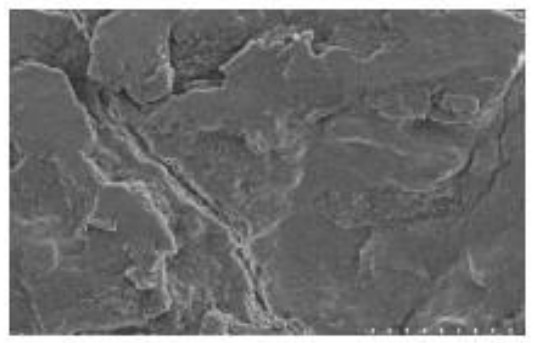

a. GDL $0.25 \%$

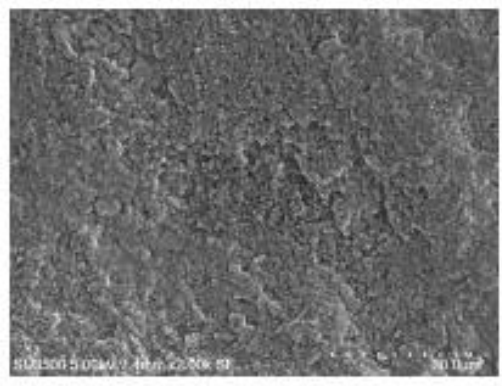

c. Nigari $0.25 \%$

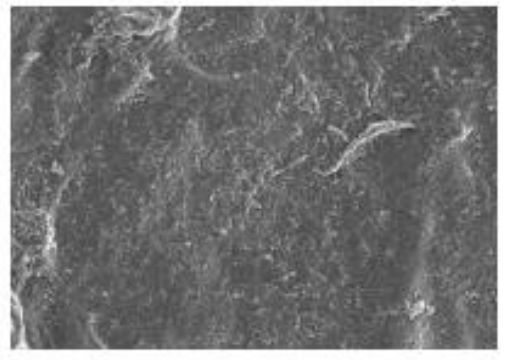

b. GDL $1 \%$

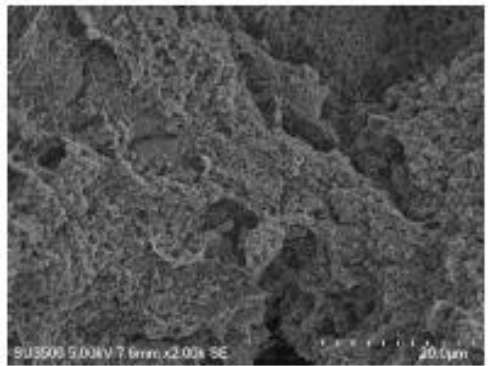

d. Nigari $1 \%$

Figure 1. SEM micrographs of jack bean tofu prepared with different coagulants and various

\subsection{Color} concentration

The results of jack bean tofu color evaluation include $\mathrm{L}^{*}, \mathrm{a}^{*}$, and $\mathrm{b}^{*}$ value are delivered in Table 6, 7, and 8, while jack bean tofu product is presented in Figure 2. 
Table 6. Effect of different coagulants and various concentrations on lightness (L) value of jack bean tofu

\begin{tabular}{cccccc}
\hline & \multicolumn{5}{c}{ Concentration (\%) } \\
Coagulants & 0.25 & 0.5 & 0.75 & 1 & \multirow{2}{*}{ Average } \\
\hline GDL & $89.23 \pm 0.50$ & $89.18 \pm 0.12$ & $89.39 \pm 0.40$ & $89.89 \pm 0.75$ & $89.42 \pm 0.52^{\mathbf{x}}$ \\
Nigari & $88.84 \pm 0.11$ & $88.76 \pm 0.70$ & $88.48 \pm 0.27$ & $88.27 \pm 0.82$ & $88.59 \pm 0.52^{\mathbf{y}}$ \\
\hline Average & $89.03 \pm 0.39$ & $88.97 \pm 0.49$ & $88.94 \pm 0.59$ & $89.08 \pm 1.13$ & \\
\hline
\end{tabular}

Table 7. Effect of different coagulants and various concentrations on redness (a value) of jack bean tofu

\begin{tabular}{cccccc}
\hline & \multicolumn{5}{c}{ Concentration (\%) } \\
Coagulants & 0.25 & 0.5 & 0.75 & 1 & Average \\
\hline GDL & $3.49 \pm 0.16$ & $3.48 \pm 0.22$ & $3.48 \pm 0.31$ & $3.46 \pm 0.32$ & $3.48 \pm 0.22^{\mathbf{x}}$ \\
Nigari & $3.64 \pm 0.12$ & $3.69 \pm 0.32$ & $3.78 \pm 0.25$ & $3.81 \pm 0.26$ & $3.73 \pm 0.22^{\mathbf{y}}$ \\
\hline Average & $3.57 \pm 0.15$ & $3.59 \pm 0.27$ & $3.63 \pm 0.30$ & $3.63 \pm 0.32$ & \\
\hline
\end{tabular}

Table 8. Effect of different coagulants and various concentrations on yellowness (b value) of jack bean tofu

\begin{tabular}{cccccc}
\hline & \multicolumn{5}{c}{ Concentration (\%) } \\
Coagulants & 0.25 & 0.5 & 0.75 & 1 & \multirow{2}{*}{ Average } \\
\hline GDL & $8.91 \pm 0.66$ & $8.84 \pm 0.42$ & $8.21 \pm 0.64$ & $8.15 \pm 0.87$ & $8.53 \pm 0.67^{\mathbf{x}}$ \\
Nigari & $9.93 \pm 0.92$ & $10.49 \pm 0.17$ & $10.72 \pm 0.76$ & $10.98 \pm 1.20$ & $10.53 \pm 0.83^{\mathbf{y}}$ \\
\hline Average & $9.42 \pm 0.90$ & $9.66 \pm 0.95$ & $9.46 \pm 1.51$ & $9.57 \pm 1.81$ & \\
\hline
\end{tabular}

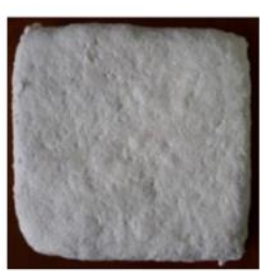

GDL $0.25 \%$

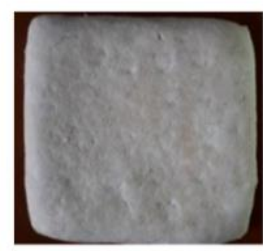

Nigari $0.25 \%$

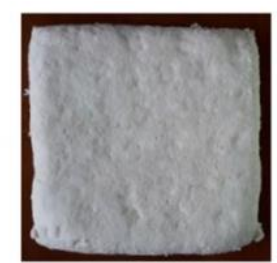

GDL $0.5 \%$

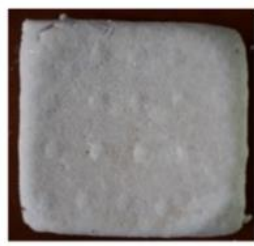

Nigari $0.5 \%$

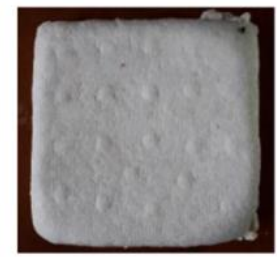

GDL $0.75 \%$

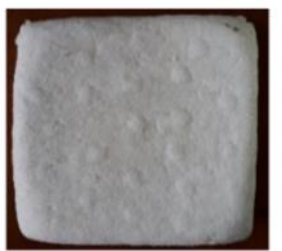

Nigari $0.75 \%$

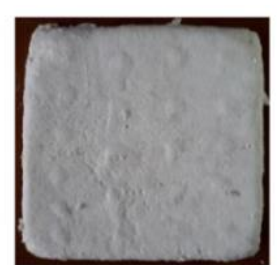

GDL $1 \%$

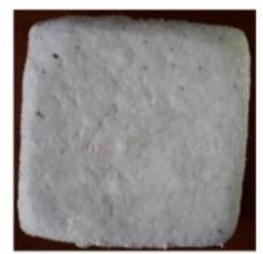

Nigari $1 \%$

Figure 2. Jack bean tofu prepare by different coagulants and various concentration

Different coagulants affected the value of $\mathrm{L}^{*}, \mathrm{a}^{*}$, and $\mathrm{b}^{*}(\mathrm{p} \leq 0.05)$, while different concentrations of coagulant did not affect the value of color attributes. According to (Kwak \& Lim, 2004), changes in brightness levels in nigari occur due to the content of $\mathrm{Mg}^{2+}$ and $\mathrm{Ca}^{2+}$ which can increase browning in sugars and amino acids contained in tofu ingredients.

\subsection{Sensory Evaluation}

The results for sensory evaluation are presented in Figure 3. 


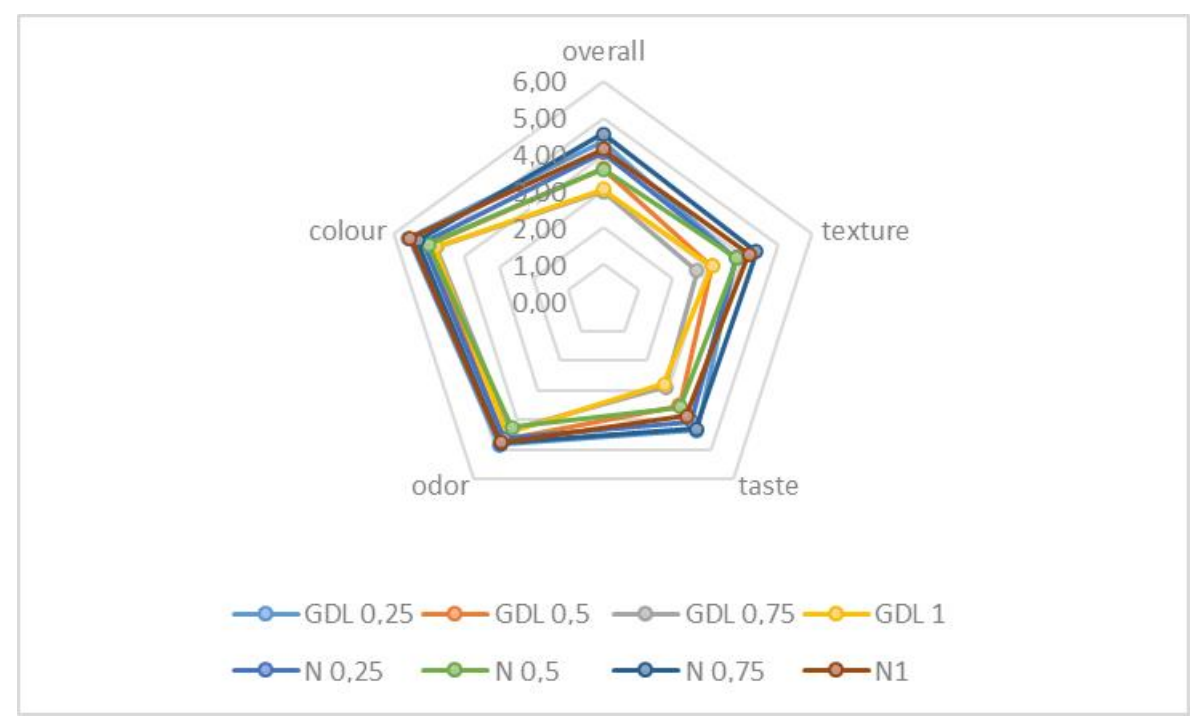

Figure 3. Sensory evaluation of jack bean tofu

Hedonic scale $(1=$ dislike very much, $2=$ dislike moderately, $3=$ dislike slightly, $4=$ neither, $5=$ like slightly, $6=$ like moderately, $7=$ like very much)

$\mathrm{GDL}=$ Gluco Delta Lactone, $\mathrm{N}=$ nigari

Color is the primary deciding factor that determines the acceptance or rejection of a product. Odor concern in the natural beany flavor of jack bean tofu. All samples have similar acceptability on color and odor. Taste is a sensation in the mouth, GDL $0.75 \%$, and GDL $1 \%$ have the lowest acceptability on taste, while nigari $0.75 \%$ and GDL $0.25 \%$ have the highest acceptability on taste. Texture and overall are the important determinant of consumer acceptability of tofu. GDL $0.75 \%$ has the lowest overall and texture acceptability, while Nigari $0.75 \%$ has the highest texture and overall acceptability.

\section{Conclusions}

Nigari is a coagulant that delivered a greater yield of jack bean tofu than GDL. It was found that different type of coagulant causes the difference in the texture attribute of jack bean tofu. The result showed nigari at concentration level $0,75 \%$ delivered the most preferred tofu for consumers. It is important to use a correct coagulant in a proper amount to produce jack bean tofu as it affects the yield and quality.

\section{Acknowledgment}

This research would not have been possible without the financial support of the Ministry of Research, Technology, and Higher Education of Indonesia.

\section{References}

AOAC. (2000). Official Methods of Analysis of AOAC International. AOAC International, 14 Gaitherburg.

BPS. (2020). Accested on August $30^{\text {th }}$ 2021. Retrieved from https://sukabumikota.bps.go.id/indicator/5/191/1/rata-rata-konsumsi-per-kapita-seminggumenurut-jenis-komoditi-makanan-kelompok-kacang-kacangan.html 
Chavan, S. M., Verma, R. C., \& teja, R. (2017). Textural and Sensory Characteristics of Freeze Dried Tofu. International Journal of Current Microbiology and Applied Sciences, 6(12), 119-128. https://doi.org/10.20546/ijcmas.2017.612.016

Guo, Y., Hu, H., Wang, Q., \& Liu, H. (2018). A novel process for peanut tofu gel: Its texture, microstructure and protein behavioral changes affected by processing conditions. $L w t$, 96(February), 140-146. https://doi.org/10.1016/j.lwt.2018.05.020

Jayasena, V., Tah, W. Y., \& Nasar-Abbas, S. M. (2014). Effect of coagulant type and concentration on the yield and quality of soy-lupin tofu. Quality Assurance and Safety of Crops and Foods, 6(2), 159-166._https://doi.org/10.3920/QAS2012.0176

Kim, D. H., Yang, W. T., Cho, K. M., \& Lee, J. H. (2020). Comparative analysis of isoflavone aglycones using microwave-assisted acid hydrolysis from soybean organs at different growth times and screening for their digestive enzyme inhibition and antioxidant properties. Food Chemistry, 305, 125462. https://doi.org/10.1016/j.foodchem.2019.125462

Kwak, E. J., \& Lim, S. I. (2004). The effect of sugar, amino acid, metal ion, and $\mathrm{NaCl}$ on model Maillard reaction under $\mathrm{pH}$ control. Amino Acids, 27(1), 85-90. https://doi.org/10.1007/s00726-004-0067-7

Li, J., Qiao, Z., Tatsumi, E., Saito, M., Cheng, Y., \& Yin, L. (2013). A Novel Approach to Improving the Quality of Bittern-Solidified Tofu by W/O Controlled-Release Coagulant. 1: Preparation of W/O Bittern Coagulant and Its Controlled-Release Property. Food and Bioprocess Technology, 6(7), 1790-1800. https://doi.org/10.1007/s11947-012-0896-4

Maneepun, S. (2003). Traditional processing and utilization of legumes. In Processing and Utilization of Legumes. Retrived from www.apo-tokyo.org

Obatolu, V. A. (2008). Effect of different coagulants on yield and quality of tofu from soymilk. European Food Research and Technology, 226(3), 467-472. https://doi.org/10.1007/s00217006-0558-8

Oboh, G. (2007). Coagulant modulates the hypocholesterolemic effect of tofu (coagulated soymilk). Journal of Medicinal Food, 10(2), 388-391. https://doi.org/10.1089/jmf.2006.208

Rekha, C. R., \& Vijayalakshmi, G. (2013). Influence of processing parameters on the quality of soycurd (tofu). Journal of Food Science and Technology, 50(1), 176-180. https://doi.org/10.1007/s13197-011-0245-z

Riniarsi, D. (2016). Outlook Komoditas Pertanian Tanaman Pangan Kedelai. (L. Nuryati, B. Waryanto, \& R. Widaningsih (eds.)). Pusat Data dan Sistem Informasi Pertanian Kementerian Pertanian.

Shen, C. F., De Man, L., Buzzel, R. I., \& Man, J. M. D. (1991). Yield and Quality of Tofu as Affected by Soybean and Soymilk Characteristics: Glucono-delta-lactone Coagulant. Journal of Food Science, 56(1), 109-112. https://doi.org/10.1111/j.1365-2621.1991.tb07987.x

Shi, Y. guo, Yang, Y., Piekoszewski, W., Zeng, J. hua, Guan, H. nan, Wang, B., Liu, L. lin, Zhu, X. qing, Chen, F. lian, \& Zhang, N. (2020). Influence of four different coagulants on the physicochemical properties, textural characteristics and flavour of tofu. International Journal of Food Science and Technology, 55(3), 1218-1229. https://doi.org/10.1111/ijfs.14357

Shurtleff, W., \& Aoyagi, A. (2000). Tofu \& soymilk production: A craft and technical manual (Vol. 2). Soyinfo Center.

Solomon, S. G., Okomoda, V. T., \& Oguche, O. (2018). Nutritional value of raw Canavalia ensiformis and its utilization as partial replacement for soybean meal in the diet of Clarias gariepinus (Burchell, 1822) fingerlings. Food Science and Nutrition, 6(1), 207-213. https://doi.org/10.1002/fsn3.548

Sridhar, K. R., \& Seena, S. (2006). Nutritional and antinutritional significance of four unconventional legumes of the genus Canavalia - A comparative study. Food Chemistry, 99(2), 267-288. https://doi.org/10.1016/j.foodchem.2005.07.049

Wang, C., Li, J., Zhou, S., Zhou, J., Lan, Q., Qin, W., Wu, D., Liu, J., Yang, W., \& Zhang, Q. (2019). Application of transglutaminase for quality improvement of whole soybean curd. Journal of Food Science and Technology, 56(1), 233-244. https://doi.org/10.1007/s13197- 
018-3480-8

Zhang, Q., Wang, C., Li, B., Li, L., Lin, D., Chen, H., Liu, Y., Li, S., Qin, W., Liu, J., Liu, W., \& Yang, W. (2018). Research progress in tofu processing: From raw materials to processing conditions. Critical Reviews in Food Science and Nutrition, 58(9), 1448-1467. https://doi.org/10.1080/10408398.2016.1263823

Zheng, L., Regenstein, J. M., Teng, F., \& Li, Y. (2020). Tofu products: A review of their raw materials, processing conditions, and packaging. Comprehensive Reviews in Food Science and Food Safety, 19(6), 3683-3714. https://doi.org/10.1111/1541-4337.12640 